DOI: $10.19195 / 0137-1150.167 .8$

SYLWIA KAMIŃSKA-MACIĄG

Uniwersytet Wrocławski, Polska

\title{
Życie po śmierci. O psychologii marzeń sennych w prozie Władimira Odojewskiego
}

O życiu po śmierci — tak Carl Gustav Jung zatytułował jeden z rozdziałów swojego dzieła Wspomnienia, sny, myśli. Spisane i podane do druku przez Aniele Jaffe ${ }^{1}$. W przywołanej części autobiografii szwajcarski psycholog snuje rozważania na temat wyobrażenia zaświatów, połączeń, jakie mogą zaistnieć pomiędzy światem żywych i martwych, oraz powodów, dla których umarli mogą ukazywać się na przykład w naszych snach. W refleksjach Junga, które — z racji braku niepodważalnych dowodów — sam autor nazywa „historyjkami” ${ }^{2}$ czy też mitologizacją, odnajdujemy idee obrazujące osobisty (to jest indywidualny dla każdego człowieka) ,tamten” świat oraz opisy związanych ze zmarłymi snów uczonego. Zawarte w rozdziale koncepcje odsyłają nas do obecnych $\mathrm{w}$ nieświadomości archetypów, których istnienie według Junga uaktywnia proces tworzenia własnej hipotezy życia po śmierci — jest to zabieg konieczny w życiu psychicznym każdego człowieka. Drogę ku lepszemu zrozumieniu tego zjawiska autor Wspomnień widzi właśnie w marzeniach sennych - tych przydarzających się nam i naszym bliskim — w których to śmierć odgrywa rolę szczególną.

Obecne w Jungowskich rozmyślaniach charakterystyczne połączenie snów i śmierci inspiruje do przyjrzenia się, z punktu widzenia psychologii głębi, romantycznej syntezie tych wykładni w twórczości Władimira Odojewskiego. Wybór krótkiej prozy fantastycznej jako materiału dla tego typu badań, a dokładniej utworów: Bajka o ciele martwym nie wiadomo do kogo przynależacym (Сказка о мёртвом теле, неизвестно кому принадлежащем, 1833) - opowiadanie pochodzące ze zbioru pisarza Pstrokate bajki (Пёстрые сказки, 1833), Szyderstwo nieboszczyka (Насмешка мертвеца, 1834) — jedna z części cyklu Odojewskiego Noce rosyjskie (Русские ночи, 1843) oraz Życie po śmierci (Живой мертвеи, 1844)

${ }^{1}$ C. G. Jung, Wspomnienia, sny, myśli, spisane i podane do druku przez Anielę Jaffe, przeł. R. Reszke, L. Kolankiewicz, Warszawa 1997, s. 259-281.

2 Ibidem, s. 259. 
wydaje się słusznym krokiem na drodze do twórczej egzegezy, przede wszystkim ze względu na klasyfikację gatunkową oraz układ świata przedstawionego we wspomnianych dziełach ${ }^{3}$. Taka reinterpretacja pozwala dostrzec inną - psychologiczną stronę motywów konwencjonalnych w literaturze rosyjskiej.

Należy podkreślić, że pojawienie się ,ż̇ywych trupów” w piśmiennictwie XIX wieku nie wprawia w zdumienie znawców literatury. Badacze podkreślają rozmaite warunki, w jakich rozwijała się fantastyka na gruncie rosyjskim, kładąc nacisk na odniesienia do romantyzmu zachodniego, często do twórczości konkretnych pisarzy, takich jak na przykład Ernst Theodor Amadeus Hoffmann. Romantyczne przeniesienie motywów związanych ze śmiercią, ich swoiste przeobrażenie, również w prozie Odojewskiego, stanowi podstawę wielu literaturoznawczych badań naukowych ${ }^{4}$. Motywom tanatologicznym przypisuje się przede wszystkim funkcje związane z wywoływaniem u czytelnika grozy - strachu przed postaciami z zaświatów. Wprowadzenie, także przez Odojewskiego właśnie, konstrukcji fabuły zasadzającej się na przemieszaniu jawy i snu, zwłaszcza w kontekście przebudzenia jako grande finale historii, miało dodatkowo intrygować współczesnego pisarzowi odbiorcę. Dziś aspekt ten traci jednak na wartości. Badacz fantastyki w prozie Odojewskiego, Józef Żuk, pisze:

Takie racjonalne zakończenie pozostawia mu [czytelnikowi - S. K. M.] uczucie zawodu, gdy przez cały czas miał wrażenie niesamowitości, która wzbudzała w nim dreszcze przerażenia. [...] Podobnego zawodu doznaje czytelnik w czasie lektury opowiadań $̇ \dot{y} w y$ trup, Kpina nieboszczyka, Bajka o martwym ciele nie wiadomo do kogo przynależacym, w których zdumiewające perypetie bohaterów wywołane są przez sen, halucynację lub majaczenie ${ }^{5}$.

Poprzez tego rodzaju konkluzję pisarz uwiarygodnia niesamowite wydarzenia, w których centrum lokował wcześniej swoich bohaterów. Zabieg ten, według Żuka, prozę „,rosyjskiego Hoffmanna” klasyfikuje już nie w gatunku fantastycznym, lecz raczej ,pseudofantastycznym", co niejednokrotnie niewątpliwie

${ }^{3}$ Warto odnieść się w tym miejscu do zbioru artykułów Marietty Turjan, w których badaczka szczegółowo omawia fabułę, motywy oraz wpływy w wybranych dziełach W. Odojewskiego; zob. М. А. Турьян, Русский „фантастический реализм”, Санкт-Петербург 2013.

${ }^{4} \mathrm{Na}$ temat romantycznych motywów w prozie rosyjskiej pisali między innymi: Ałła Botnikowa (zob. А. Б. Ботникова, Э. Т. А. Гофман и русская литература первой половины ХІХ в. К проблеме русско-немеиких литературных связей, Воронеж 1977), Tatiana Czebaniuk (zob. T. A. Чебанюк, Фантастическая повесть в историко-литературном процессе 20-х-начала 40-х годов ХІХ века, Москва 1979), Maria Janion (zob. M. Janion, Goraczka romantyczna, Warszawa 1975) czy Kazimiera Lis (zob. K. Lis, Romantycy. Powinowactwa rosyjsko-europejskie, Kielce 1998).

5 J. Żuk, Element fantastyki w romantycznych nowelach Włodzimierza Odojewskiego lat trzydziestych XIX wieku, „Rusycystyczne Studia Literaturoznawcze” 1977, nr 1, s. 38, http:// docplayer.pl/46141363-Jozef-zuk-element-fantastyki-w-romantycznych-nowelach-wlodzimierza-odojewskiego-lat-trzydziestych-xix-wieku.html [dostęp: 13.04.2017].

${ }^{6}$ Uczony pisze: „Typowym przykładem takiej pseudofantastyki jest Trumniarz Puszkina” —ibidem, s. 38. 
ujmuje uroku interpretowanym dziełom ${ }^{7}$. Przyjrzenie się z psychoanalitycznej perspektywy snom o śmierci od tej tendencji na pewno odbiega.

Warto raz jeszcze podkreślić, że poszukiwanie odpowiedzi na pytania o to, jak wygląda „tamten świat” oraz jakie związki pomiędzy światem żywych i umarłych zachodzą, Jung określa jako arcyważny element życia psychicznego każdego człowieka. „Nieświadomość — pisze uczony — dzięki przekazom i obrazowym aluzjom, daje nam pewną szansę [aby odnaleźć odpowiedź na owe pytania S. K. M.], jest bowiem w stanie powiadomić nas o czymś, czego zgodnie z wszelką logiką wiedzieć nie możemy"8. Oznacza to, że między innymi poprzez marzenia senne nieświadomość może odesłać nas do pewnych znaczeń, mitów, które im bardziej przyswoimy, „tym więcej życia włączymy w całość naszego istnienia”. Oczywiście, aby móc dobrze te komunikaty zinterpretować, należałoby odnieść sny zarówno do wewnętrznych, jak i zewnętrznych kontekstów dotyczących życia osoby badanej ${ }^{10}$. Na przykładzie losów protagonistów Odojewskiego możemy jednak odkryć kilka desygnatów, wskazujących nie tylko na pewne wyobrażenie życia po śmierci, lecz także na potrzebę rozwoju psychicznego dziewiętnastowiecznego bohatera literatury rosyjskiej.

\section{Wyobrażenie 1: dusza pozbawiona ciała ${ }^{11}$}

Opowiadanie Bajka o ciele martwym nie wiadomo do kogo przynależacym tylko pozornie sugeruje, iż główną postacią jest w nim trup. Ciało pozbawione duszy jest tu jedynie rekwizytem, zaś istotne miejsce zajmują w dziele rozważania natury socjalnej ${ }^{12}$.

Refleksje socjologiczne (przede wszystkim krytyka funkcjonariuszy publicznych, stopień ich zbiurokratyzowania) Odojewski wprowadza do utworu w formie dialogu pomiędzy urzędnikiem państwowym niskiej rangi, prowadzącym dochodzenie w sprawie odnalezionego, niezidentyfikowanego ciała osoby zmarłej - Iwanem Sewastianowiczem, a błąkającą się po śmierci duszą. Jak możemy się domyślać, tuż po całym zajściu główny bohater budzi się, z przykrością stwierdzając, iż poprzedniego wieczoru sam osuszył całą butelkę mocnego trunku. Odojewski, w typowy dla siebie groteskowy sposób, całą zaistniałą sytuację umieszcza zatem w sferze snu (tu dodatkowo zakropionego alkoholem). Niemniej

${ }^{7} \mathrm{Na}$ temat motywów fantastycznych w prozie Odojewskiego w Polsce pisała, oprócz wspomnianego już J. Żuka, także Olga Główko; zob. eadem, Idee romantyzmu w „, Nocach rosyjskich” Włodzimierza Odojewskiego, Łódź 1997.

${ }^{8}$ C. G. Jung, Wspomnienia, sny, myśli, s. 261.

${ }^{9}$ Ibidem.

$10 \mathrm{O}$ praktycznym zastosowaniu nauki Junga w procesie interpretacji snów pisze Jolande Jacobi w dziele Psychologia C. G. Junga, przeł. G. Glodek, G. Glodek, Poznań 2014, s. 101-125.

11 „W opowiadaniach Odojewskiego można wydzielić trzy rodzaje postaci fantastycznych: ciało pozbawione duszy, dusza pozbawiona ciała i postacie o nadprzyrodzonych siłach" — J. Żuk, Element fantastyki..., s. 41.

12 Ibidem. 
jednak i w takim, mocno realistycznym zakończeniu opowiadania pisarz pozostawia nam uchyloną furtkę do różnych interpretacji zjawisk w dziele przedstawionych. Czytamy bowiem:

Эти слова напомнили Севастьянычу ночное происшествие, и как оно ни странно ему казалось, но он вспомнил о пятидесяти рублях, обещанных ему просителем, если он выхлопочет ему тело, и серьезно стал требовать от заседателя и лекаря, чтоб тело не вскрывать, потому что этим можно его перепортить, так что оно уже никуда не будет годиться, а просьбу записать во входящий обыкновенным порядком. Само собою разумеется, что на это требование Севастьянычу отвечали советами протрезвиться, тело вскрыли, ничего в нем не нашли и похоронили ${ }^{13}$.

Choć oczywiste wydaje się tu podkreślenie pogardliwego stosunku autora względem chciwego bohatera, zwątpienie Sewastianowicza nasuwa na myśl jeden z procesów psychologicznych opisanych przez C. G. Junga, a dokładniej: zasadę kompensacji ludzkiej psyche. $\mathrm{Z}$ tego punktu widzenia warto zauważyć, że dusza Twerleya Johna Lewisa, którego to Sewastianowicz przerabia w dokumentach na Sawielija Żałujewa (Цвеерлей-Джон-Луи = Савелий Жалуев), objawia się urzędnikowi jako przerywnik rozmyślań przy kieliszku nalewki. Bieg strumienia świadomości ${ }^{14}$ bohatera pozwala nam określić pewien kontekst, sytuujący go nie tylko w jego realnej rzeczywistości (wspomina swoje pochodzenie, zajmowane stanowisko oraz ścieżkę kariery), lecz przede wszystkim kontekst psychiczny (stosunek do świata, pracy i otaczających go ludzi stanowi o narcystycznym, egoistycznym i mocno ograniczonym usposobieniu bohatera).

Fakty te skłaniają do refleksji na temat dążności psyche do rozwoju, między innymi właśnie poprzez skierowanie świadomości na nieuświadomione archetypy w śnie bohatera. Zagubiona dusza z marzenia sennego Sewastianowicza może uosabiać tę część psychiki bohatera skrywającą się w zakamarkach jego osobowości, która dąży do uzewnętrznienia, do „oddania jej ciała”. Ma bowiem zupełnie odwrotne względem urzędnika cechy charakteru - dusza cudzoziemca jest miła, rzeczowa, a nawet hojna, bo za szybkie załatwienie sprawy skłonna sporo zapłacić. To właśnie różne typy postaw, jakie obrazują te postaci, kierują nas ku symbolice kompensacyjnej funkcji psychiki ludzkiej. Według psychologii jungowskiej umysł skierowany wyłącznie jednostronnie, jak mogło mieć miejsce w wypadku Sewastianowicza, domaga się uzupełnienia, co może sygnalizować pojawienie się przeciwstawnego typologicznie ducha we śnie bohatera. Jolande Jacobi, autorka wielu cenionych prac z zakresu psychologii głębi, objaśnia:

$\mathrm{Z}$ reguły orientacja nieświadomości jest komplementarna lub kompensacyjna w stosunku do aktualnej sytuacji świadomości. „Im bardziej świadoma postawa jest jednostronna i oddalona od optymalnych możliwości życiowych, tym wcześniej dana jest możliwość, aby

13 В. Ф. Одоевский, Сказка о мертвом теле, неизвестно кому принадлежащем, http:// az.lib.ru/o/odoewskij_w_f/text_0280.shtml [dostęp: 30.04.2017].

14 O końcu biegu strumienia świadomości pisze się, że przerywa go zazwyczaj głębokie omdlenie lub sen; zob. J. Trzópek, Na tropach podmiotu. Między filozoficznym a empirycznym ujęciem podmiotowości, Kraków 2013. 
bogate $\mathrm{w}$ treści sny pod postacią silnie kontrastującego, ale koniecznie skompensowanego aspektu wystąpiły jako wyraz psychologicznego autonomicznego przejścia sterów przez jednostkę", gdzie kompensacyjny charakter snu jest naturalnie głęboko złączony z istotą człowieka ${ }^{15}$.

Prośba Sewastianowicza (wciąż niewierzącego, że całe to zdarzenie rzeczywiście miało miejsce ${ }^{16}$ ) o niewykonywanie zaplanowanej sekcji zwłok z punktu widzenia psychologii głębi może obrazować pewne zmiany, jakie nastąpiły w $p s y$ che bohatera. Wspomniana nagroda, owe pięćdziesiąt rubli obiecanych bohaterowi przez duszę cudzoziemca, może bowiem symbolizować bogactwo duchowe przyswojenie treści nieświadomych zawartych w snach stanowi podstawę rozwoju, którego efektem jawi się osiągnięcie pełni osobowości. „Dzięki temu jednostka ponownie ustawi się z prądem, narodziny i śmierć oznaczać już będą tylko przechodnie etapy, a sens życia nie ograniczy się tylko do ego"17. Co więcej, człowiek, który osiąga pełne zespolenie części jego świadomości i nieświadomości, przestaje odczuwać strach przed śmiercią, widząc ją raczej w aspekcie kolejnego etapu na drodze swojego istnienia. Choć prośba Sewastianowicza spotyka się z odrzuceniem, kpiną, pogardą — co miało obrazować porażkę zamkniętego na wszystko, co sprzeczne z regulaminem/przyjętymi normami społeczeństwa w perspektywie psychoanalitycznej może oznaczać, niekoniecznie udaną, aczkolwiek podjętą, próbę rozwoju psychicznego protagonisty. Wnioskiem zdaje się zatem spostrzeżenie, że zmarły, pojawiający się we śnie urzędnika, symbolizuje część jego samego, czyli element nieświadomości dążący do uświadomienia, czy też dążność psychiki do rozwoju w ogóle. Podobne stanowisko zajmował i sam Jung, opisując swoje własne doświadczenia snów o zmarłych ${ }^{18}$.

\section{Wyobrażenie 2: ciało pozbawione duszy}

W Szyderstwie nieboszczyka rolę bohatera z zaświatów odgrywa już nie inteligentna, komunikatywna dusza, lecz ciało zupełnie pozbawione życia. Obecność martwego młodzieńca, nawiedzającego we śnie piękną Lizę, miała wywołać w czytelniku nie tylko poczucie strachu, lecz przede wszystkim stać się bodźcem do rozważań na temat problemów natury etyczno-moralnej ${ }^{19}$. Zarówno to jedno ciało, jak i całokształt wizji śmierci określonego społeczeństwa, jaką przedstawia

\footnotetext{
15 J. Jacobi, Psychologia C. G. Junga, s. 110-111.
}

16 Jung również miewał podobne wątpliwości: „Nagle doznałem uczucia, że zmarły jest w moim pokoju. Miałem wrażenie, że stoi w nogach mego łóżka. Nie czułem się tak, jakbym ujrzał widmo; była to wewnętrzna wizualizacja zmarłego, którą wziąłem za fantazję. Gwoli uczciwości musiałem jednak zadać sobie pytanie: jaki mam dowód, że to fantazja? A jeśli to nie fantazja, jeśli mój przyjaciel naprawdę stoi w nogach mego łóżka, to czy nie jest to niestosowne, że biorę go za wytwór fantazji?" - idem, Wspomnienia, sny, myśli, s. 269-270.

17 J. Jacobi, Psychologia C. G. Junga, s. 199.

18 C. G. Jung, Wspomnienia, sny, myśli, s. 261.

19 Zob. J. Żuk, Element fantastyki..., s. 41. 
Odojewski w utworze, mają skłonić odbiorcę do zadumy nad losem ludzkości. Jednakowoż właśnie to konkretne spotkanie — młodej dziewczyny z jej zmarłym adoratorem — odsyła badacza zorientowanego psychoanalitycznie do jungowskiej potrzeby rozwoju osobowości. Przy czym lokacja tego utworu w orbicie powiązań psychologicznych sprawia, że nasuwa się pytanie o to, kogo powinniśmy tu nazywać ciałem pozbawionym duszy? Główną bohaterkę Lizę autor opisuje bowiem jako kobietę, która:

Покорилась не чувству, - нет, она затоптала святую искру, которая было затеплилась в душе ее, и, падши, поклонилась тому демону, который раздает счастье и славу мира. [...] И все было презрено; и бескорыстная любовь юноши, и силы, которые она оживляла... ${ }^{20}$

Z kolei miłość zmarłego młodzieńca definiuje jako uczucie zespalające „wszystko, co w człowieku jest święte i piękne"21. W przedstawionej w opowiadaniu wizji nikczemność ludzką pisarz topi w fali powodzi, zalewającej tańczących gości na sali balowej. Topiącą się Lizę z opresji może uratować tylko unosząca się na powierzchni wody trumna. $\mathrm{Z}$ jej wnętrza z pogardą uśmiecha się do dziewczyny martwe ciało odrzuconego kochanka:

Пораженная его взором, она то оставляет гроб, то снова, мучась невольною любовью к жизни, хватается за него, — и снова гроб нагибается и лицо мертвеца висит над ее лицом, - и снова дождит на него холодными каплями, — и, не отворяя уст, мертвец хохочет: „Здравствуй, Лиза! благоразумная Лиза...”- и непреоборимая сила влечет на дно красавицу ${ }^{22}$.

W takich oto okolicznościach bohaterka budzi się w swoim łóżku po tym, jak — według relacji świadków — zemdlała na balu.

Senną wizję Lizy — miraż śmierci w otchłani wody — możemy traktować jako ostrzeżenie. Odojewski dokładnie opisuje cechy społeczeństwa, które niczym biblijny potop ma zmyć wzbierająca fala rzeki ${ }^{23}$. „Wyrachowanie, chłodna kalkulacja zdolna jest zniszczyć nie tylko uczucie, lecz zabić człowieka" ${ }^{24}$ — pisze Adam Bezwiński, interpretując motto opowiadania. Liza, będąc księżną, jest nie tylko

${ }^{20}$ В. Ф. Одоевский, Насмешка мертвеиа, [w:] idem, Русские ночи, Ленинград 1975, s. 49.

${ }^{21}$ Zob. A. Bezwiński, Dziesięć nowel z „Nocy rosyjskich” Włodzimierza Odojewskiego, „Acta Universitatis Lodziensis” 1988, nr 22, s. 87.

22 В. Ф. Одоевский, Насмешка мертвеияа, s. 52.

23 „Между толпами бродят разные лица; под веселый напев контрданса свиваются и развиваются тысячи интриг и сетей; толпы подобострастных аэролитов вертятся вокруг однодневной кометы; предатель униженно кланяется своей жертве; здесь послышалось незначущее слово, привязанное к глубокому, долголетнему плану; там улыбка презрения скатилась с великолепного лица и оледенила какой-то умоляющий взор; здесь тихо ползут темные грехи и торжественная подлость гордо носит на себе печать отвержения... [...] там еще танцуют, там еще говорят о будущем, там еще думают о вчера сделанной подлости, о той, которую надобно сделать завтра; там еще есть люди, которые ни о чем не думают" ibidem, s. 50.

${ }^{24}$ A. Bezwiński, Dziesięć nowel..., s. 87. 
częścią tej wspólnoty - jest jej szablonowym paradygmatem. Rezygnując z miłości, ze szczęścia pojmowanego poprzez pryzmat duchowy, dziewczyna jest też dobrym przykładem pewnego ograniczenia, jakie nastąpiło w rozwoju jej psyche. W jungowskiej perspektywie pojawiająca się we śnie Lizy trumna ze zwłokami młodzieńca uosabiającego uczucia czyste, skierowane na drugą osobę, a nie tylko do wewnątrz, sygnalizuje potrzebę dopełnienia czy też zwrotu kierunku rozwoju psychicznego. Egoistycznie nastawione ego dziewczyny wymaga kompensacji. Według szwajcarskiego psychiatry „rozwój osobowości jest jednocześnie łaską i przekleństwem; trzeba je słono okupić, ponieważ oznacza osamotnienie. »Jego pierwszą konsekwencją jest świadoma i nieunikniona izolacja jednostki od niewyróżniającego się i nieświadomego stada «"25. Liza tego wyzwania się nie podejmie. Może to sygnalizować wzgardliwy uśmiech, jakim obdarza ją zmarły młodzieniec. Nieuświadomiona część pozostanie w ukryciu. $Z$ tej perspektywy ciekawa wydaje się również diagnoza stanu księżnej, postawiona przez miejscowego lekarza:

- Изволите видеть, - говорил доктор, - это очень ясно: всякое сильное движение души, происходящее от гнева, от болезни, от испуга, от горестного воспоминания, всякое такое движение действует непосредственно на сердце; сердце в свою очередь действует на мозговые нервы, которые, соединясь с наружными чувствами, нарушают их гармонию; тогда человек приходит в какое-то полусонное состояние и видит особенный мир, в котором одна половина предметов принадлежит к действительному миру, а другая половина к миру, находящемуся внутри человека...

Opisane przez medyka odniesienie do zmian zachodzących w głębi ludzkiej duszy, przejawiających się poprzez marzenia senne, pozwala nam wierzyć, że psychoanalityczną interpretację losów Lizy wskazywał już sam Odojewski. Niemniej jednak zakończenie historii nie przynosi rozwiązania: słów lekarza nie słucha nawet mąż kobiety, a inni uczestnicy balu wydają swoją diagnozę (,дамские причуды!"26). Liza zaś odrzuci jeszcze jedną wielką miłość, co stanie się powodem kolejnego samobójstwa ${ }^{27}$.

\section{Wyobrażenie 3: życie po śmierci}

Wydawać by się mogło, że polska wersja językowa tytułu kolejnego interpretowanego tu przez nas opowiadania, to jest $\grave{Z} y$ cie po śmierc ${ }^{28}$, sugeruje, jakoby przedstawione w nim zdarzenia mogły rozgrywać się w zaświatach. Jednak próby opisu świata umarłych Odojewski w nim nie podejmuje. Oryginalny tytuł dzieła (Живой мертвеи) podpowiada jedynie stan, w jakim znajduje się główny

25 J. Jacobi, Psychologia C. G. Junga, s. 144.

26 В. Ф. Одоевский, Насмешка мертвеияа, s. 52.

27 Zakończenie to stanowi wstęp do kolejnej historii nocy czwartej z Nocy Rosyjskich Ostatniego samobójstwa.

28 Zob. W. Odojewski, Życie po śmierci, [w:] Straszna wróżba. Rosyjska nowela fantastyczna pierwszej połowy XIX wieku, red. W. Korowin, przeł. E. Zychowicz, Warszawa-Moskwa 1988, s. 316-340. 
bohater, akcja zaś utworu została umiejscowiona we współczesnej pisarzowi Rosji. Równie przyziemny jest i finał historii, a dokładniej znany już nam motyw wybudzenia ze snu:

В это утро Василий Кузьмич проснулся очень поздно. Он долго не мог прийти в себя, протирал глаза и смутно озирался. - Что за глупый сон! — сказал он наконец, - индо лихорадка прошибла. Что за страхи мне снились, и как живо - точно наяву... отчего бы это? да! вчера я поужинал немного небрежно, да еще лукавый дернул меня прочесть на сон грядущий какую-то фантастическую сказку... Ох, уж мне эти сказочники! Нет чтоб написать что-нибудь полезное, приятное, усладительное! а то всю подноготную из земли вырывают! Вот уж запретил бы им писать! ${ }^{29}$

Groteskowość takiego rozwiązania zostaje jeszcze bardziej uwydatniona za pomocą usprawiedliwień, jakimi posiłkuje się po przebudzeniu bohater w ramach pozbywania się poczucia winy. Nie dość, że wszystkie opisane w dziele zajścia miały pozostać $\mathrm{w}$ sferze snu, to związane $\mathrm{z}$ nimi nieprzyjemne odczucia protagonista tłumaczy sobie to przejedzeniem, to niefortunną lekturą. Sny o życiu po śmierci, jakie przydarzają się Wasilijowi Kuzmiczowi, są zatem, według słów pisarza, efektem bujnej wyobraźni bohatera, pobudzonej dodatkowo bajaniami nieprzyjemnymi, lecz pokazującymi całą prawdę o świecie historiami fantastycznymi. Niewątpliwie takie rozwiązanie skłania nas, aby na obecne w opowiadaniu marzenie senne spojrzeć również z perspektywy psychoanalitycznej. W tym wypadku możemy się bowiem kierować nie tylko wskazówkami zawartymi we wspomnieniach Junga, lecz także ową symboliczną sugestią samego pisarza.

Warto podkreślić, iż w nietypowej dla swoich krótkich opowiadań fantastycznych formie ${ }^{30}$ Odojewski przedstawia nam dzień z życia bohatera, który budzi się — w swoim mniemaniu — martwy. Wizja życia po śmierci, jaka została wykreowana przez pisarza już na początku tej historii, zasadza się na możliwości podglądania świata żywych z perspektywy oddzielonej od ciała duszy. Czyżby zaświaty miały zatem według Odojewskiego nie istnieć? Duch Wasilija Kuzmicza nie odchodzi bowiem do krainy wiecznego szczęścia, nie ulatuje w górę, w stronę nieba, lub też na odwrót - do piekielnej głębi. Pozostaje on dokładnie w tej samej rzeczywistości, w której znajdował się za życia, z jedyną tylko zmianą, że poza swoim ziemskim ciałem. „Wyobrażenia, jakie ludzie mają na temat tamtego świata — pisał Jung — są rezultatem myślenia życzeniowego i przesądów [...]”31. Życzeniem bohatera Odojewskiego było podejrzenie życia bliskich, przyjaciół i współpracowników, a przede wszystkim ich reakcji na śmierć całkiem przyzwoitego — jak o sobie myślał ${ }^{32}$ — człowieka. Z psychoanalitycznego punktu

29 В. Ф. Одоевский, Живой мертвеu, http://az.lib.ru/o/odoewskij_w_f/text_0460.shtml [dostęp: 28.04.2017].

${ }^{30}$ Całość opowiadania stanowi monolog wewnętrzny głównego bohatera połączony z dialogami rodem z dramatu.

31 C. G. Jung, Wspomnienia, sny, myśli, s. 276.

32 „А награда, наказанье? Впрочем, правду сказать, награды я не ждал, - не за что; да и наказывать меня не за что; были кое-какие грешки... ну, да у кого их нет? Я истинно скажу: ни добра, да и ни зла без нужды я никому не делал - право... вы знаете: я человек Slavica Wratislaviensia 167, 2018

(C) for this edition by CNS 
widzenia to, czym kierować się mogła psyche zmarłego, daje się poznać jako pragnienie wiedzy. Podróż, jaką odbywa po śmierci dusza Kuzmicza, przepełniona jest zdarzeniami, z których każde moglibyśmy interpretować jako dążenie do pogłębienia świadomości — rozwoju jaźni. W swoich wspomnieniach Jung pisał:

Jeśli miałaby istnieć jakaś forma świadomego bytowania po śmierci, byłoby z nią tak jak ze świadomością ludzkości, która w określonym czasie osiąga jakiś określony, choć dający się podnieść poziom. Wielu ludzi śmierć dopadła, kiedy jeszcze pozostawali nie tylko poniżej własnych możliwości, ale także — i przede wszystkim — poniżej tego, co już za ich życia inni zdołali sobie uświadomić. Stąd ich roszczenia, by choćby w stanie śmierci posiąść wiedzę, której nie zdobyli za życia. Do tego wniosku doszedłem zajmując się snami o umarłych ${ }^{33}$.

Zgodnie z tym twierdzeniem dusza zmarłego protagonisty wędruje w poszukiwaniu wiedzy o sobie i owo wtajemniczenie osiąga. Jakkolwiek w tym przypadku nie prowadzi ono do rozwoju osobowości. Dwie pierwsze wizje (kiedy to bohater jest świadkiem rozmowy swoich współpracowników oraz najlepszego przyjaciela z Księciem - obu zasadzających się na stopniowym odkrywaniu negatywnych cech bohatera) przynoszą jedynie rozczarowanie. Wasilij Kuzmicz nie jest gotowy na to, aby zaakceptować i pogodzić się z informacjami, jakie otrzymał, a krytyką swojej osoby po prostu się nie przejmuje. Cechy Kuzmicza, które czytelnikowi dają się poznać poprzez wypowiedzi innych bohaterów, z perspektywy psychologii Junga moglibyśmy nazwać Cieniem ${ }^{34}$ urzędnika. Postawa wyparcia całkowicie eliminuje jednak rozwój osobowościowy, który miałby tu polegać na wchłonięciu, to jest poznaniu oraz zaakceptowaniu swojego ,mrocznego brata”. Tymczasem protagonista postanawia dość lekkodusznie ${ }^{35}$ przenieść się w miejsce, w którym jest pewien usłyszeć na swój temat jakieś komplementy. Kolejne spotkania przynoszą jednak coraz większe rozgoryczenie. Oszust, skąpiec, łajdak, leń — kolejne opinie powoli wytrącają bohatera z równowagi. Splot wydarzeń sprawia, iż jest on świadkiem upadku jedynej osoby, która żywiła wobec niego ciepłe uczucia — bratanicy Lizy. I to właśnie ta sytuacja budzi w Kuzmiczu pierwsze wyrzuty sumienia:

Так вот жизнь, вот и смерть! Какая страшная разница! В жизни, что бы ни сделал, все еще можно поправить; перешагнул через этот порог — и все прошедшее невозвратно! [...] Бедная Лиза! Как вспомню об ней, так душа замирает! А всему виною я, я один! я внушил эту несчастную мысль моим детям — и чем! неосторожным словом, обыкновенною мирскою шуткою! Но виноват ли я? [...] ох! это совесть, совесть! какое страшное слово! как оно странно звучит в слухе! оно кажется мне совсем иным, нежели каким там казалось; это какое-то чудовище, которое давит, душит и грызет мне сердце ${ }^{36}$.

откровенный; ну, разумеется, когда ждешь беды, то иногда, так сказать, и подставишь ногу ближнему... да что ж тут делать? человек на тебя лезет с ножом, неужели же ему шею подставить?" - В. Ф. Одоевский, Живой мертвецุ.

33 C. G. Jung, Wspomnienia, sny, myśli, s. 267.

${ }^{34}$ Cień w psychologii Junga to „ciemna strona” naszej osobowości, skłonność, która została odrzucona, najczęściej z powodu moralnego lub etycznego; zob. J. Jacobi, Psychologia C. G. Junga, s. 148-154. 35 „А, право, весело этак из места в место летать” — В. Ф. Одоевский, Живой мертвец.
36 Ibidem.

Slavica Wratislaviensia 167, 2018

(C) for this edition by CNS 
W taki oto sposób uwydatnione zostały wszystkie negatywne cechy bohatera. Ma on możliwość ich uświadomienia, widzi bowiem swój Cień, wciąż może zatem przejść pierwszy etap rozwoju psyche, w tym wypadku pośmiertnie. Zakończenie historii daje bohaterowi jeszcze więcej możliwości — wybudzony ze snu może uświadomić sobie swoją „,ciemną stronę”. „Przepracowanie Cienia w dużej mierze - choć z nieco innym akcentem - odpowiada temu, do czego zmierza psychoanaliza, odkrywając poszczególne elementy historii jednostki [...]"37. Jednak proces, jaki rozpoczął się w psyche bohatera Odojewskiego, nie zostaje przez niego podjęty. Pisarz zaś usilnie krytykuje tu moralność określonej warstwy społecznej. Wyrazista jest również myśl o psychologicznej potrzebie, a zarazem niemożności rozwoju jego bohaterów.

Choć $\mathrm{w}$ artykule podejmujemy zagadnienia związane z życiem po śmierci, z duszami zmarłych i nieboszczykami, ich pojawianiem się w naszej doczesności i snach, to nauka płynąca z refleksji C.G. Junga dotyczy de facto nie zmarłych, lecz żywych.

Jedynie tutaj — pisał twórca psychologii głębi — w życiu ziemskim, gdzie zdarzają się przeciwieństwa, można podnieść ogólny poziom świadomości. Wydaje się, że podnoszenie tego poziomu stanowi metafizyczne zadanie człowieka ${ }^{38}$.

Sny o śmierci, jakie przydarzają się bohaterom Odojewskiego, zdają się wskazówką, jaką otrzymują wymagający rozwoju psyche protagoniści. W opowiadaniach rosyjskiego pisarza zmarli ożywają, dusze wychodzą z ciała, a ciała uśmiechają się pogardliwie - wszystko po to, aby wskazać na jakiś konkretny, żywy w XIX wieku problem natury społecznej czy etyczno-moralnej. Natomiast repetycja psychoanalityczna marzeń sennych bohaterów pozwala odnieść się również do problematyki ogólnoludzkiej, bo dotyczącej rozwoju psyche każdego człowieka.

\section{Bibliografia}

Bezwiński A., Dziesięć nowel z „,Nocy rosyjskich” Włodzimierza Odojewskiego, „Acta Universitatis Lodziensis" 1988, $\mathrm{nr} 22$.

Główko O., Idee romantyzmu w „Nocach rosyjskich” Włodzimierza Odojewskiego, Łódź 1997.

Jacobi J., Psychologia C. G. Junga, przeł. G. Glodek, G. Glodek, Poznań 2014.

Janion M., Goraczka romantyczna, Warszawa 1975.

Jung C. G., Wspomnienia, sny, myśli. Spisane i podane do druku przez Anielę Jaffe, przeł. R. Reszke, L. Kolankiewicz, Warszawa 1997.

Lis K., Romantycy. Powinowactwa rosyjsko-europejskie, Kielce 1998.

Odojewski W., Życie po śmierci, [w:] Straszna wróżba. Rosyjska nowela fantastyczna pierwszej połowy XIX wieku, red. W. Korowin, przeł. E. Zychowicz, Warszawa-Moskwa 1988.

Trzópek J., Na tropach podmiotu. Między filozoficznym a empirycznym ujęciem podmiotowości, Kraków 2013.

37 J. Jacobi, Psychologia C. G. Junga, s. 149.

38 C. G. Jung, Wspomnienia, sny, myśli, s. 269. 
Żuk J., Element fantastyki w romantycznych nowelach Włodzimierza Odojewskiego lat trzydziestych XIX wieku, „Rusycystyczne Studia Literaturoznawcze” 1977, nr 1, http://docplayer. pl/46141363-Jozef-zuk-element-fantastyki-w-romantycznych-nowelach-wlodzimierzaodojewskiego-lat-trzydziestych-xix-wieku.html.

Ботникова А. Б., Э. Т. А. Гофман и русская литература первой половины ХІХ в. К проблеме русско-немецких литературных связей, Воронеж 1977.

Одоевский В. Ф., Живой мертвеu, http://az.lib.ru/o/odoewskij_w_f/text_0460.shtml.

Одоевский В. Ф., Насмешка мертвецฺа, [w:] idem, Русские ночи, Ленинград 1975.

Одоевский В. Ф., Сказка о мёртвом теле, неизвестно кому принадлежащем, http:/az.lib. ru/o/odoewskij_w_f/text_0280.shtml.

Турьян М. А., Русский „фантастический реализм”, Санкт-Петербург 2013.

Чебанюк Т. А., Фантастическая повесть в историко-литературном проиессе 20-х-начала 40-х годов ХІХ века, Москва 1979.

\section{Life after death: About the psychology of dreams in the works of Vladimir Odoyevsky}

\section{Summary}

The way to a better understanding of what happens to a human soul after death, Carl Gustav Jung saw in dreams, in which the death played a special role. The characteristic Jungian combination of dreams and death inspired the author of the article to look at the romantic synthesis of the same interpretations in nineteenth-century Russian literature from the perspective of depth psychology. The selection of short, fantastic prose by Odoyevsky for this type of research, more precisely: The tale of a dead body belonging to no one knows whom - story from the writer's collection Gaudy tales, Taunting dead man - one of the parts of the notorious cycle of the writerThe Russian nights and The living corpse, proved to be the right move on the path to creative exegesis, primarily due to the genre classification and world system presented in the mentioned writer's stories. Such reinterpretation allowed the perception of yet another, psychological, side of the conventional motifs in Russian literature. The thanatological motifs are primarily attributed to the function of triggering the horror in a reader - the fear of characters from the afterlife. On the example of Odoyevsky's protagonists dreams, several designates were revealed, indicating not only a certain imagination of life after death but also the need for mental development of the nineteenth-century Russian literature character.

Keywords: Vladimir Odoyevsky, fantasy, psychoanalysis, death, archetype

\section{Жизнь после смерти. О психологии сновидений в произведениях Владимира Одоевского}

\section{Резюме}

Путь к лучшему осмыслению идей о том, что происходит с человеческой душой после смерти, основоположник аналитической психологии Карл Густав Юнг видел в сновидениях, особенно в тех, в которых смерть играла главную роль. Содержащееся в размышлениях психолога характерное соединение сновидений и смерти вдохновило автора этой статьи 
исследовать, с точки зрения глубинной психологии, романтический синтез тех же самых качеств в русской литературе XIX века. Малая фантастическая проза Владимира Федоровича Одоевского, в частности произведения: Сказка о мертвом теле, неизвестно кому принадлежащем - рассказ, помещенный в сборнике писателя Пестрые сказки; Насмешка мертвеца - одна из частей известной серии Русские ночи, а также Живой мертвец, для такого рода исследований оказались хорошим материалом особенно ввиду их жанровой классификации и особенностей фиктивного мира в упомянутых выше произведениях. Такой обзор позволил увидеть другую, психологическую сторону конвенционных мотивов в русской литературе, поскольку танатологическим мотивом приписываются прежде всего функции, связанные с вызовом страха у читателя. На примере снов героев Одоевского обнаружено несколько референтов, указывающих не только определенное воображение жизни после смерти, но также на потребность „психического развития” героев в русской литературе XIX века.

Ключевые слова: Одоевский, фантастика, психоанализ, смерть, архетип 